\title{
KONSEP DIRI MAHASISWI TRI WANGSA (STUDI DRAMATURGI MAHASISWI BERPACARAN BEDA WANGSA DI SINGARAJA)
}

\author{
Viki Mardiyanto ${ }^{*}$ \\ ${ }^{1}$ Universitas Negeri Malang, Indonesia \\ “e-mail: vikimardiyanto98@gmail.com
}

\begin{abstract}
Abstrak
Dalam pernikahan yang ada di Bali idealnya adalah dilakukan dalam kasta atau wangsa yang setara agar tidak terjadi pernikahan nyerod. Namun ternyata banyak ditemukan kasus mahasiswi triwangsa berpacaran dengan laki-laki dari kasta di bawahnya dan ini membuat para mahasiswi dari golongan triwangsa berusaha untuk menyembunyikan status hubungan mereka dari keluarganya. Artikel mengkaji fenomena ini dari sudut pandang subjektif mahasiswi tri wangsa ini terkait dengan konsep diri mereka. Informan adalah tiga orang mahasiswi dari golongan triwangsa. Hasil dari artikel ini menunjukan bahwa ternyata mahasiswi tri wangsa dalam kaitannya dengan konsep diri, mengembangkan sebuah setting yang berbeda baik secara ruang maupun secara sosialnya, setting tersebut antara lain panggung depan yang merupakan rumah dan panggung belakang kampusnya. Ketika berada di rumah mahasiswi triwangsa memanajemen kesan sealami mungkin untuk menutupi hubungannya. Mahasiswi triwangsa memanfaatkan kehidupan kampus sebagai panggung belakangnya, untuk mempertahankan pola ini mahasiswi triwangsa berusaha untuk memistifikasi jarak antar masing-masing latar.
\end{abstract}

Kata kunci: Pernikahan; Nyerod; Mahasiswi Triwangsa; Dramaturgi

\begin{abstract}
Bali marriage tradition, ideally, Balinese will be married to a person who has the same caste to avoid nyerod. However, there's still a lot of case that Triwangsa female student has a relationship with a guy who has lower social stratification, thus making them have to hide their relationship status. This article aims to study this phenomenon more deeply from the Triwangsa female student's subjective point of view with their self-concept. This article's result shows that the students of Triwangsa, concerning their self-concept, developed a different setting both physically and socially. The set included the front stage, the house, and the backstage, which is the campus. While at home, they're trying to manage the impression as naturally as possible to cover up the relationship. Besides, they're also used campus life to be their backstage to maintain these two patterns. Triwangsa students tried to modify the distance between each background.
\end{abstract}

Keywords: Marriage; Nyerod; Triwangsa; Student; Dramaturgy

\section{PENDAHULUAN}

Dalam tradisi pernikahan Bali terdapat norma-norma yang harus di patuhi untuk melaksanakan sebuah pernikahan yang berlaku untuk setiap anggota masyarakatnya. Karena masyarakat di Bali memiliki stratifikasi sosial atau sebuah susunan masyarakat yang bersifat bertingkat, tingkatan ini di Bali biasa disebut dengan kasta atau dalam bahasa Bali disebut Wangsa yang terpengaruh oleh pembagian kasta di masyarakat Hindu India dimana tinggi rendahnya derajat seseorang dilihat berdasarkan garis keturunannya (Sudarsini, 2018). Wangsa dalam masyarakat Bali terbagi menjadi empat tingkatan atau Catur Wangsa yakni Brahmana Wangsa, Ksatriya Wangsa, Waisya Wangsa, dan Sudra Wangsa atau Jaba Wangsa (Karepun 2017). Namun dalam implementasinnya sendiri terdapat berbagai macam kebingungan terkait terutama terkait konsep warna dan konsep kasta. Kasta sendiri sebenarnya sudah tidak relevan dalam ajaran agama hindu dan diganti dengan warna namun faktanya sampai saat ini masyarakat masih banyak 
yang terpengaruh dengan konsep kasta. Pelabelan kasta yang disalahgunakan oleh orang-orang jaman dahulu membentuk sebuah tradisi yang harus dijalankan oleh keturunannya. Sifat dan karakter umat Hindu yang selalu memegang teguh sesuatu yang dianggap sebagai tradisi warisan leluhur semakin memperkuat posisi kasta dan mengaburkan istilah warna, sehingga tidak mengherankan jika sampai saat ini bahkan masa yang akan datang, kasta tetap memiliki porsi tersendiri dalam membedakan derajat seseorang (Sudarsini, 2018). Dalam artikel ini sendiri akan menggunakan konsep kasta ini untuk dikaji pengaruhnya dalam kehidupan masyarakat Bali, walaupun kasta sendiri merupakan sebuah konsep yang seharusnya ditinggalkan namun pengaruhnya masih menarik untuk dikaji lagi lebih dalam. Dalam sebuah pernikahan orang Bali sangat disarankan untuk menikah se-linear dengan orang yang berasal dari Wangsa dengan tingkatan yang sama agar tidak terjadi pernikahan dengan beda kasta atau yang disebut Nyerod Wangsa. Pengertian lebih spesifik dari istilah ini adalah kondisi dimana perempuan yang berasal dari golongan Tri Wangsa yakni Brahmana, kesatriya dan waisya menikah dengan golongan jaba wangsa atau Tri Wangsa namun lebih rendah tingkatannya.

Dalam sistem kekerabatan masyarakat Bali garis keturunan berasal dari pihak laki-laki atau patrilineal (Asmarajaya, 2017). Sistem ini membuat anak-anak mengikuti garis keturunan dari ayah. Hal ini menyebabkan perempuan yang berasal dari kasta Tri Wangsa memiliki kecenderungan untuk menikah dengan laki-laki yang sepadan dengan kastanya. Namun masih ada saja kasuskasus menikah nyerod wangsa yang ditemukan di masyarakat. Dulu perkawinan beda kasta memiliki konsekuensi hukum yang sangat berat bagi yang melaksanakannya baik bagi mempelai lakilaki maupun perempuan. Konsekuensi hukum yang dimaksud dimulai dari penurunan kasta bagi mempelai perempuan sesuai dengan kasta mempelai laki-laki, hukuman buang ke luar Bali yang dikenal dengan sebutan selong bagi kedua mempelai, bahkan sampai hukuman labuh gni dan labuh batu. Labuh gni dan labuh batu ini merupakan hukuman mati (Widetya, 2015).

Berpacaran merupakan salah satu cara yang dilakukan oleh seorang individu yang memiliki tujuan untuk pencarian jodoh, yang merupakan tahapan sebelum siklus hidup orang dewasa yakni menikah, siklus ini biasa di alami dalam usia remaja atau usai dewasa awal. Proses pencarian jodoh ini merupakan salah satu proses sosialisasi yang akan di alami oleh setiap individu. Menurut (Ihromi, 1999) dalam proses berpacaran ini juga akan berpengaruh pada tingkat kepuasan individu terhadap pernikahan mereka (Ardhianita \& Andayani 2005). Hal ini juga berkaitan dengan proses sosialisasi pada masa dewasa. Proses sosialisasi ini berkaitan dengan tiga hal yakni bekerja, menikah dan mempunyai anak. Proses fase sebelum menikah atau pemilihan jodoh ini salah satunya diambil dengan jalan berpacaran. Namun pemilihan sosok pacar atau jodoh ini juga dipengaruhi oleh nilai-nilai yang di dapatkan individu dari psoses sosialisasi. Kita ketahui bahwa dalam sosialisasi kita tidak bisa lepas agen dari sosialisasi ini yang akan berpengaruh pada nilai-nilai yang di sosialisasikan, selain sosialisasi primer yaitu keluarga, sosialisasi sekunder juga berpengaruh pada sosialisasi nilai-nilai yang dalam konteks ini adalah pemillihan jodoh.

Dalam masa dewasa awal sendiri khusunya mahasiswi faktor-faktor seperti lingkungan interaksi yang begitu majemuk menyebabkan ditemukan beberapa kasus seorang perempuan dewasa awal dengan kasta Tri Wangsa yang berpacaran dengan kasta Jaba Wangsa. Hal ini sangat bertentangan dengan prinsip dimana pernikahan di Bali sebaiknya adalah dengan kasta yang sederajat (Sukerti, Agung, \& Ariani 2018). Karena tujuan dari berpacaran adalah proses pencarian dan pemilihan jodoh, maka idealnya tujuan atau muara utama dari berpacaran adalah mengacu kepada pernikahan. Kondisi seperti ini seringkali menyebabkan dilema khususnya bagi perempuan tersebut karena walaupun sanksi dari nyerod tidaklah begitu kuat seperti dulu namun masih saja banyak hal yang akan merugikan perempuan yang melakukan pernikahan nyerod. Hal-hal yang merugikan bagi perempuan yang menjalani perkawinan berbeda wangsa salah satu diantaranya adalah larangan ke rumah kelahirannya sendiri, hal semacam ini menyebabkan bias gender dalam perkawinan beda wangsa (Sudarma, 2015). Karena sangat banyak dampak secara sosial dan budaya yang akan dirasakan oleh perempuan yang menjalani pernikahan nyerod, serta dengan tujuan untuk mempertahankan kasta keluarga 
maka tidak jarang keluarga dan orang tua juga ikut ambil bagian dalam pemilihan jodoh sang anak. Keluarga baik keluarga batih atau kelaurga besar seringkali menetapkan standart pria ideal yang diinginkan untuk anak-anak perempuan mereka, syarat utama dari dari kriteria keluarga ini adalah berada dalam kasta yang sama. Namun saat ini sangat banyak kita temukan perempuan dari golongan tri wangsa yang berpacaran bahkan menikah dengan pria dari golongan jaba wangsa ataupun masih dari golongan tri wangsa namun lebih rendah kastanya. Konsekuensi dari pernikahan beda kasta adalah tidak adanya restu dari keluarga pihak perempuan dan menyebabkan pernikahan yang akan dilakukan hanya bisa dilakukan melalui kawin lari, hal ini juga berimplikasi pada ketidak terbukaan sang anak kepada orang tuanya ketika mereka mulai menjalin hubungan berpacaran dengan pria dari kasta di bawah mereka.

Dalam pemilihan jodoh pada perempuan dewasa awal dari golongan tri wangsa khususnya yang ber-irisan dengan nyerod wangsa terdapat dua peneliian terdahulu yang relevan dan dapat digunakan sebagai bahan pijakan untuk penulisan artikel ini lebih lanjut. Dalam penelitian-penelitan tersebut dalam kaitanya dengan pemilihan jodoh maka variable pola asuh orang tua tidak bisa dipisahkan ketika membahas hal ini. Jenisjenis pola asuh orang tua tertentu juga akan berimplikasi pada tingkat kecemasan perempuan dalam memilih jodohnya, dan juga pola asuhan tertentu juga beimplikasi pada kecenderungan dalam memilih pasangan secara homgamy, atau dari golongan memiliki kesamaan secara sociocultural dengannya (Adi \& Tobing 2018; Alit \& Lestari 2014). Kedua artikel tersebut sama-sama menyoroti hubungan korelasional antara pola pengasuhan dan implikasinya terhadap aspek psikologi dari perempuan golongan tri wangsa dalam memilih jodohnya. Namun ada beberapa hal yang kurang di sorot dalam penelitianpenelitian tersebut yakni tentang konsep diri dari yang ada dalam diri secara subjektif dari para perempuan golongan tri wangsa tersebut. Kenapa konsep diri menjadi penting untuk dikaji lebih lanjut lagi karena dalam ranah subjektif artikel ini ingi mengeksplorasi bagaimana proses tahapan dalam diri manusia ketika melakukan tindakan dalam sebuah setting sosial tertentu.
Artikel ini memiliki kebaharuan dibandingkan dengan penelitian-penelitian serupa yang membahas tentang nyerod wangsa. Kebaruan pertama adalah nyerod wangsa yang di bahas dalam artitikel ini secara waktu berada dalam tahap atau kondisi pra-nikah, khususnya dalam masa berpacaran. Kedua karena nyerod wangsa adalah sebuah fenomena sosio-kultural yang dapat diteliti dari banyak aspek dengan menggunakan beberapa sudut pandang dalam sosiologi baik makro maupun mikro. Dalam artikel ini peneliti mencoba menggunakan pespektif mikro yang berguna untuk mendapatkan fakta subjektif dari fenomena memilih jodoh pada perempuan tri wangsa yang berpacaran dengan pria dengan kasta yang lebih rendah. Hal yang dapat kita cermati disini adalah yang pertama adalah bagaimana pola pikir yang di bentuk dan faktor-faktor yang mempengaruhi sehingga memutuskan untuk menjalin hubungan dengan pria dari kasta yang lebih rendah. Bagaimana konsep diri dari seorang perempuan tri wangsa dalam berinteraksi dengan latar setting sosial yang berbeda dan menjemen kesan yang ditampakkan dalam setting sosial yang berbeda, serta bagaimana tindakan yang dilakukan dalam menyembunyikan status hubungannya dari pengetahuan keluarga inti dan keluarga besarnya.

\section{METODE}

Dalam artikel ini menggunakan pendekatan kualitatif yang didalamnya terdapat beberapa metode yang dapat dipilih, dari metode-metode ini terdapat beberapa tradisi yang dapat dipilih sesuai dengan masalah penelitian yang akan di angkat, (Creswell, 2007) menyebutkan bahwa terdapat lima jenis metode yang biasa digunakan dalam pendekatan kualitatif yakni : Fenomenologi, Grounded Theory, Ethnografi, Studi Kasus dan Penelitian Naratif. Penelitian ini menggunakan desain penelitian fenomenologi untuk memahami secara utuh fenomena subjektif yang dirasakan oleh perempuan berusia dewasa awal dengan kasta Tri Wangsa dalam persepsi mereka terhadap pernikahan nyerod wangsa serta latar balakang dari pengambilan keputusan untuk berpacaran dengan laki-laki berkasta lebih rendah. Dalam kaitannya dengan penelitian ini tujuan dipilihnya desain penelitian fenomenologi ini adalah karena ingin menujukkan sebuah realitas yang obyektif yang mewujud dari pengalaman 
subjektif dari para perempuan berusia dewasa awal dengan kasta Tri Wangsa di Singaraja.

Data yang digunakan dalam artikel ini adalah data primer yang diambil dengan melalui beberapa tahapan. Tahapan yang pertama adalah pencarian data melalui observasi non partisipan yang merupakan observasi dimana peneliti hadir secara fisik dalam lingkungan atau setting sosial informan namun informan tidak menyadari jika sedang di amati, hal ini dilakukan dengan tujuan untuk melihat perilaku informan dalam lingkungan sosialnya secara natural. Hal yang diamati oleh peneliti adalah interaksi yang dilakukan informan dengan lingkungan sosial di kampusnya. Hal ini berhubungan dengan pencarian data pada tahapan yang kedua yakni melalui indepth interview yang memiliki tujuan untuk menggali data tentang perbedaan perilaku dan tindakan ketika berinteraksi ditengan-tengah lingkungan keluarganya. Hal ini dilakukan berkaitan untuk menggali cara-cara dari masing-masing informan dalam manajemen kesan yang ditampilkan pada keluarga mereka untuk tujuan menyembunyikan fakta tentang hubungan pacaran dengan pria dari kasta di bawahnya yang sedang dijalani. Penentuan informan pada artikel ini dilakukan dengan teknik purposive sampling, yakni pemilihan informan yang dilakukan secara sengaja berdasarkan kriteria yang telah ditentukan dan ditetapkan berdasarkan pada masalah yang diangkat dalam artikel. Kriteria informan dalam penelitian ini adalah perempuan dengan usia dewasa awal berstatus tri wangsa yang tengah berada pada hubungan berpacaran dengan laki-laki yang memiliiki kasta yang lebih rendah.

\section{HASIL DAN PEMBAHASAN}

Dalam pandangan tentang diri, Erving Goffman merupakan salah satu teoritisi interaksionisme simbolik yang membahas tentang diri. Diri yang dikaji oleh Goffman dalam (Ritzer, 2008) secara konsepsi tidak bisa terlepaskan dari konsep dari mead, terutama tentang ketegangan antara "l", yang merupakan diri yang spontan serta manusiawi dan konsep diri "me" yang merupakan konsep diri yang telah tersosialisas. Lebih lanjut lagi Goffman membahas tataran konsep diri ini dapat dianalogikan seperti pertunjukan drama atau disebut Teori Dramaturgi. Dalam pertunjukan yang ditampilkan oleh masing-masing individu ini sama seperti konsep drama yang memiliki panggung dengan dua sisi yakni depan dan belakang, dan aktor juga akan memiliki tindakan yang berbeda dalam setting panggung yang berbeda atau dalam hal ini adalah setting sosialnya.

Dalam kaitannya dengan konsep diri dari mahasiswi tri wangsa ini perlu digali lebih lanjut lagi sebagai refleksi dari bagaimana secara subjektif mereka mengatur dan bisa melakukan hubungan berpacaran yang dilarang oleh keluarganya. Dalam tataran ini selain membicaraka motif kita lebih berfokus pada cara atau proses serta tahapan dari diri aktor mahasiswi tri wangsa tersebut dalam mengakomodasi setting sosial yang berbeda dan dapat menyembunyikan tindakan terlarang yang dilakukannya pada setting sosial keluarganya ketika ia berada pada setting sosial yang lain yakni lingkungan kampusnya. Konsep diri yang saling bertentangan dan sang aktor yang melakukan sedemikian rupa manajemen diri dan kesan pada masing-masing setting sosial menjadi relevan untuk dikaji lebih lanjut menggunkan Teori Dramaturgi dari Goofman. Untuk dapat memahami korelsi antara konsep diri mahasiswi tri wangsa dan juga Teori Dramaturgi itu sendiri maka pertama perlu data informan yang dipaparkan secara terpisah untuk pemahaman yang lebih komprehensif lagi, dan kemudian ditarik sintesis dari setiap informan dengan pecahan konsep-konsep yang ada dalam Teori Dramaturgi.

\section{Latar Belakang Keluarga dan Status Hubungan Mahasiswi Tri Wangsa}

Ketiga Informan memiliki perbedaan dalam latar belakang keluarga terutama jika dikaitkan dengan konsep warna yang dalam konteks ini masih di implementasikan seperti sistem kasta dan memiliki hubungan secara langsung dengan garis keturunan. Informan pertama merupakan seorang dari keturunan golongan kasta Brahmana yang dan dalam keluarga besarnya merupakan penganut hindu yang cukup taat dan sangat menjaga nilai-nilai kagamaan serta norma-norma yang ada. Saat ini informan sudah tidak berhubungan dengan pria dengan kasta di bawahnya, namun ia pernah tiga kali menjalin hubungan dengan pria dari golongan kasta di bawahnya. Namun dari ketiga mantan pacarnya tersebut ada satu orang yang pernah diajaknya mengunjungi rumahnya dan bertemu dengan orang tuanya, dan seperti yang sudah bisa di 
duga orang tuanya tidak merestui hubungan tersebut. Informan kedua memiliki garis keturuan golongan kasta Brahmana dan keluarganya terutama keluarga besarnya sangat taat terhadap ajaran agama hindu bahkan kakek dari informan adalah seorang pendeta. Hal ini juga berimplikasi pada ketatnya pemilihan jodoh ketika informan menjalin hubungan dengan seorang laki-laki. Informan ketiga merupakan anak dari keturuanan keluarga kesatrya wangsa, walaupun keluarganya cukup taat namun informan sendiri bukan merupakan orang yang terlalu fanatik dengan agamanya, hal ini dibuktikan dari kurangnya intensitas ibadah yang dilakukannya dibandingkan dengan temanteman hindu dalam lingkungan kampusnya yang lain. Secara garis besar para informan memiliki perbedaaan latar belakang keluarga dan juga pada tingkat religiusitasnya, namun kesamaan dari ketiga informan ini adalah sama-sama memiliki latar belakang secara konsep kasta yang berada pada garis keturunan yang tinggi dan sama-sama pernah menjalin hubungan dengan pria dari kasta keluarga yang lebih rendah daripada kasta keluarga yang mereka miliki.

\section{Perbedaan Interaksi Sosial Mahasiswi di kampus dan di Rumah}

Jika dilihat dari hubungan antara informan dengan orangtuanya, informan mengalami beberapa fase dalam hubungannya dengan orang tua. Fase-fase ini adalah dimulai dengan ketika berumur sekolah menengah pertama hubungan informan dengan orang tua tidak dekat, informan merasa tidak diperhatikan dan kurang afektif dari kedua orangtuanya kemudian hubungan dengan kedua orangtuanya sat ini mulai membaik dibandingkan pada ketika umur sekolah menengah pertama. Saat ini informan di kampus menempati tempat indekos karena jarak dari kampus dan rumahnya yang jauh, hal ini menyebabkan kesempatan orang tua untuk berinteraksi dengan informan hanya ketika informan pulang ke rumah sekitar sebulan sekali atau ketika ada acara keagamaan dan selain itu hanya berinteraksi via telfon. Jika ditinjau dari hubungan dengan orang tua nampaknya informan tidak terlalu dekat dengan orangtunya hal ini dapat dilihat dari ketidakterbukaan dengan kedua orangtuanya karena pola asuh yang otoritarian di dalam keluarganya. Ketidakterbukaan dengan orang tua ini juga dapat kita lihat dari informan yang sama sekali tidak pernah membicarakan tentang semua laki-laki yang pernah berhubungan dengannya. Hal ini membuat informan benar-benar memanfaatkan jarak dengan keluarganya dalam menjalin hubungan dengan kekasinnya. Hal ini juga dilakukan dengan harapan status hubungannya tidak diketahui oleh orangtuanya dan juga keluarga besarnya. Tingkat kedekatan informan dengan orangtuanya bisa dibilang tidak terlalu dekat karena orangtuanya juga cukup otoritarian dalam mengasuh anak. Hal ini ditunjukan dengan laranganlarangan untuk keluar malam dan lain sebagainya dari orangtuanya. Namun walaupun informan secara jarak tidak terpisah jauh seperti informan lainnya. Nampaknya informan juga masih bisa memanfatkan alasan kegiatan kampusnya untuk menyembunyikan hubungan percintaanya dari orangtuanya.

\section{Panggung Depan dan Belakang Mahasiswi Tri Wangsa}

Dalam teori dramaturgi terdapat konsep-konsep di dalamnya, salah satunya adalah pembagian setting tempat dan sosial yang dibagi menjadi dua yakni panggung depan dan belakang. Kedua hal tersebut berkaitan dengan bagaimana aktor harus bersikap berbeda pada masingmasing setting dan sikap yang ditamplikan pada masing-masing setting. Pada panggung depan dan belakang seringkali tingkah laku aktor sangat bertentangan karena hal ini masih berhubungan dengan pertentangan dalam konsep diri antara "I" dan "Me". "l" adalah diri aktor yang sebenarnya sementara "me" adalah diri aktor yang bersosialisi dengan lingkungan sosialnya.

Pertentangan dalam diri mahasiswi triwangsa hadir sebagai pertentangan antara rasa cinta terhadap kekasihnya dan pertentangannya dengan nilai-nilai dalam masyarakat yang dijunjung tinggi oleh keluarganya. Karena pertentangan inilah yang menjadikan mahasiswi triwangsa membuat garis perbedaan yang cukup besar pada perilaku mereka pada masingmasing area panggung. Panggung ini terkait pada dua hal yakni tempat dan yang kedua lebih penting lagi adalah setting sosial. Kedua hal ini berkaitan erat dengan bagaimana aktor harus berperilaku. Dalam kasus mahasiswi triwangsa terutama dalam konteks mereka yang menyembunyikan status pacaran dengan pria dari kasta dibawahya hal ini membuat secara otomatis 
rumah dan juga keluarga yang ada di dalamnya menjadi paggung depan dimana aktor harus memainkan sandiwaranya sebaik mungkin atau secara singkatnya mahasiswi tri wangsa berusaha untuk tampak seperti normal dalam usaha menutupi status hubungannya dengan kekasihnya ketika berada di rumah atau ketika berinteraksi dengan keluarganya.

Hal ini akan tampak berbeda ketika mahasiswi tri wangsa berada pada lingkungan kampusnya, karena berusaha menutupi hubungan dengan kekasihnya dalam lingkungan keluarga akhirnya mahasiswi tri wangsa memanfaatkan kehidupan kampusnya sebagai panggung belakang. Dalam lingkungan kampus yang sebagai panggung belakang ini terlihat para mahasiswi lebih bebas terutama dalam mengekspose hubungan percintaanya. Keterbukaan ini terjadi karena dalam lingkungan kampus para mahasiswi triwangsa ini sebagian besar berinteraksi dengan temannya sendiri, hal ini pulalah yang menyebabkan terjadinya keterbukaan.

Dikotomi latar tempat dan juga latar sosial di masing-masing tempat ini harus di pelihara sedemikian rupa oleh para mahasiswi triwangsa. Pemeliharaan ini terkait dengan cara berperilaku di masingmasing tempat dengan tujuan agar audiens atau disini merupakan keluarga mereka dapat tetap percaya dengan peran yang sedang mereka mainkan. Oleh karena itu dibutuhkan juga menjemen kesan yang baik agar peran yang tengah dimainkan terlihat meyakinkan. Manajemen kesan merupakan salah satu konsep lain yang ada dalam teori dramaturgi. Menejemen kesan ini terkait dengan kesan yang ditunjukan pada orang tua terkait kompetensi dari para aktor dalam dunia kampusnya. Hal ini seringkali mengelabuhi orang tua dan keluarga tentang tindakan mereka yang sebenarnya diluar itu dalam interaksinya di kampus. Oleh karena itu kesan yang ditampilkan kepada orangtua para mahasiswi triawangsa adalah mahasiswi yang rajin dengan kehidupan kampus yang sibuk sehingga keluarga tidak berpikir lebih jauh lagi bahkan mengungkit tentang hubungan percintaanya. Selain manajemen kesan yang baik mahasiswi triwangsa juga membutuhkan jarak yang cukup antara panggung depan dan panggung atau hal ini disebut dengan mistifikasi.

Mistifikasi dengan tujuan untuk menjaga jarak audiens yang ada pada panggung depan dengan aktor dalam fenomena ini terletak pada pemanfaatan kehidupan kampus. Mahasiswi triwangsa dalam mistifikasi ini menggunakan jarak antara rumah dan tempat kosnya dengan baik untuk menutupi hal tersebut. Namun berbeda dengan informan yang ketiga dimana ia tidak bisa memanfaatkan jarak karena ia harus pulang kerumah setiap harinya dan berinteraksi dengan orangtuanya. Namun strategi mistifikasi yang dipakai adalah kesibukan dalam dunia kampus dan kesan yang ditampilkan yang membuat jarak secara emosional diantara anak dan orangtuanya. Jarak secara emosional ini sangat perlu untuk menutupi hubungan para mahasiswi triwangsa dengan pacarnya dari orangtua mereka.

\section{SIMPULAN DAN SARAN}

Untuk menghindari perkawinan nyerod wangsa maka para keluarga dan orangtua di Bali memililki kriteria idelnya dalam urusan jodoh anaknya. Namun dalam tataran subjectif sang anak terkadang bertentangan dengan keinginan orangtuanya. Dalam kasus mahasiswi triwangsa status kemahasiswaannya ini dapat dimanfaatkan sebagai sebuah panggung belakang dalam menjalin hubungan berpacaran dengan pria dari kasta dibawahnya. Kemudian rumah dan keluarga mereka menjadi panggung depan dimana mahasiswi triwangsa menjadi aktor dan memainkan perannya. Dalam mendukung permainan peran ini mahasiswi triwangsa juga menggunakan menejemen kesan dan juga mistifikasi jarak dengan orangtua mereka untuk menutupi hubungan dengan kekasihnya yang merupakan golongan kasta dibawahnya.

\section{DAFTAR PUSTAKA}

Adi, I. A. R. P., \& Tobing, D. H. (2018). Perbedaan Tingkat Kecemasan Dalam Pemilihan Pasangan Wanita Triwangsa Dewasa Awal Di Bali Yang Ditingjau Berdasarkan Pola Asuh Otoritarian. Jurnal Psikologi Udayana, $5(1)$. Https://Doi.Org/10.24843/Jpu.V5i01.3 9281

Alit, I. A., \& Lestari, M. D. (2014). Hubungan Pola Asuh Authoritative Dengan Kecenderungan Homogamy Dalam Pemilihan Pasangan Pada Wanita Bali Dewasa Awal Wangsa Brahmana Di Denpasar. Jurnal Psikologi Udayana. Https://Ojs.Unud.Ac.Id/Index.Php/Psi kologi/Article/View/25129 
Viki Mardiyanto | Konsep Diri Mahasiswi Tri Wangsa (Studi Dramaturgi Mahasiswi Berpacaran Beda Wangsa Di Singaraja)

Ardhianita, I., \& Andayani, B. (2005). Kepuasan Pernikahan Ditinjau Dari Berpacaran Dan Tidak Berpacaran. Jurnal Psikologi, 32(2).

Asmarajaya, I. M. (2017). Sistem Kekerabatan Kepurusa Di Bali. Jurnal Advokasi Fh Unmas, 7(1).

Creswell, J. W. (2007). Qualitative Inquiry \& Research Design Choosing Among Five Approaches. Sage Publications.

Ihromi, T. O. (1999). Bunga Rampai Sosiologi Keluarga (1 Ed.). Yayasan Obor Indonesia.

Karepun, Kembar. (2017). Menarik Benang Kusut Kasta. Sage.

Ritzer, G. (2008). Teori Sosiologi Dari Teori Sosiologi Klasik Sampai Perkembangan Mutakhir Teori Sosial Postmodern. Kreasi Wacana.

Sudarma, I. P. (2015). Bias Gender Dalam Perkawinan Beda Wangsa Pada Masyarakat Hindu Di Bali. Jurnal Multikultural \& Multireligius, 14(3), 8.

Sudarsini, N. N. (2018). Kasta Dan Warna: Sebuah Kritik Dalam Masyarakat Egaliter. 21(1), 7.

Sukerti, N. N., Agung, I. G. A., \& Ariani. (2018). Budaya Hukum Masyarakat Adat Bali Terhadap Eksistensi Perkawinan Beda Wangsa. Jurnal Magister Hukum Udayana, 7(4). Https://Doi.Org/10.24843/Jmhu.2018. V07.104.P07

Widetya, A. B. C. (2015). Akibat Hukum Perceraian Terhadap Kedudukan Perempuan Dari Perkawinan Nyerod Beda Kasta Menurut Hukum Kekerabatan Adat Bali. Jurnal Hukum Universitas Brawijaya. 